rehabilitation of science and scientific education in these two countries. In Belgium, Prof. Finch will be the guest of the Académie Royale des Sciences, des Lettres et des Beaux-Arts in Brussels, and in Holland he will be the guest of the Koninklijke Akademie van Wetenschappen.

Prof. I. M. Heilbron, professor of organic chemistry in the Imperial College of Science and Technology, and Dr. L. H. Lampitt, who are chairman and secretary of the British National Committee for Chemistry, have left on a visit to Paris to reestablish contact with French men of science. They hope to discuss informally the revival of international collaboration in science.

\section{Nova Tamm}

A TELEGRAM from Copenhagen announces the discovery by Dr. Tamm of a nova in the constellation of Aquila. It is thought that the nova will be named after its discoverer. On August 28, the date of its discovery, its visual magnitude was about 7 and its photographic magnitude $8 \cdot 5$. It was stated that there was a strong continuous spectrum with emission lines.

Dr. W. H. Steavenson observed the nova and gave more precise co-ordinates than those originally supplied. Its position, according to Dr. Steavenson, is R.A. 19h. $16 \mathrm{~m}$. 31s., Dec. $+0^{\circ} 31 \cdot 6^{\prime}$; equinox $1945 \cdot 0$; comparison stars $+0.4173^{\circ}$ and $+0 \cdot 4178^{\circ}$. Dr. Steavenson observed the nova on August 31 and found that it was pure white to the eye. Numerous bright lines in the spectrum, especially in the green and blue regions, were seen. $\mathrm{He}$ estimated the magnitude (visual) as 7:9. A later communication from Copenhagen states that the photographic magnitude originally given was very inaccurate. On August 30 it was $7 \cdot 6$. The position of the nova is now given as R.A. 19h. $16 \mathrm{~m} .30 \cdot 64 \mathrm{~s} .$, Dec. $+0^{\circ} 3 \mathrm{l}^{\prime} 45 \cdot 4^{\prime \prime}$.

\section{Announcements}

The Lord President of the Council has appointed Prof. H. Munro Fox, professor of zoology in the University of London (Bedford College), Prof. I. M. Heilbron, professor of organic chemistry in the Imperial College of Science and Technology, London, and Dr. C. C. Paterson, director of the Research Laboratories of the General Electric Co., Ltd., to be members of the Advisory Council to the Committee of the Privy Council for Scientific and Industrial Research from October 1. Prof. A. V. Hill, Sir Felix Pole and Sir Robert Robinson retired from the Council on completion of their terms of office on September 30 .

The Council of the Institute of Welding has awarded the Sir William J. Larke Medal for 1945 , together with a first prize of $£ 50$, to Mr. W. K. B. Marshall of the Aluminium Plant and Vessel Co., Ltd., for a paper entitled "The Fabrication of Aircraft Fuel Tanks in Aluminium Alloy containing 3\% Magnesium". The second prize has been awarded to Mr. J. Corston MacKain, of Redpath Brown and Co., Ltd. A third prize was awarded to the late Mr. H. W. Clark, formerly assistant engineer (bridges and struct. ures) to the London Passenger Transport Board ; Mr. Clark was the winner of the Medal in 1944. The fourth prize goes to Mr. R. W. Arden, of Peterborough.

The Theobald Smith Gold Medal of the American Academy of Tropical Medicine has been awarded to Dr. C. M. Wenyon, formerly director of the Wellcome Foundation Research Laboratories. The Medal will be presented to Dr. Wenyon in London through the United States Embassy.
The Veterinary Educational Trust has made the following awards: Boots Undergraduate Scholarships ( $£ 150$ per annum): M. H. Cross (University of Liverpool), G. Shattock (Royal Veterinary College), G. Sumner Smith (University of Liverpool), H. S. Taylor (University of Liverpool). Halford Undergraduate Scholarships (£100 per annum): Gordon Cox (Royal Veterinary College), D. C. Croft (University of Liverpool). All the scholarships are awarded for the full course of study for the diploma of M.R.C.V.S. These awards bring the total of undergraduate scholarships so far awarded by the Trust up to eighteen. In addition, eight research fellowships of an annual value of $£ 450$ - $£ \$ 00$ have been awardod for the investigation of veterinary problems of urgent importance.

The following appointments have been made in the University of Sheffield: Mr. L. Mirsky to be assistant lecturer in mathematics; Dr. J. A. Pope to be lecturer in mechanical engineering.

The following resignations have taken place: Dr. E. T. Goodwin, lecturer in mathematics; $\mathrm{Mr}$. J. H. Read, lecturer in chemistry ; Dr. J. Shirley, lecturer in geology; Dr. W. Davies, temporary assistant lecturer in geology ; Colonel R. G. Bellamy, lecturer in mechanical engineering; Miss M. C. Simpson, assistant bacteriologist.

THE Genetical Society is holding special meetings during October 31-November 2, at which several European geneticists will describe work and thought in that field in their own countries, and British geneticists will speak on progress in Britain. The meetings will be held at the London School of Hygiene and Tropical Medicine, Keppel Street, London, W.C.l.

THE Society of Czechoslovakian Mathematicians and Physicists is arranging a conference on the use of X-ray metheds in the metal industry to be held in Prague during November 21-25. Some twenty-five Czech specialists and also invited guests from foreign countries will deliver lectures on the application of $\mathrm{X}$-rays to the study of foundry sands, electrolytically deposited metals, deformation in polyerystalline materials, light alloys, fatigue in metals, welding, etc. ; and on the use of gamma rays on material testing. The lectures will be published as a booklet. More detailed information about the conference can be obtained from Dr. V. Vand, 16 Woodburn Boulevard, Bebington, Cheshire, or directly from the Society of Czechoslovakian Mathematicians and Physicists, Prague II, Žitná 25, Czechoslovakia.

TeE Council of the Polish Medical Association in the British Empire is appealing for books, text-books and periodicals which are urgently needed in Poland. During the German occupation, not only were no new books published but also the existing libraries were robbed and the most valuable books confiscated. The final stages of the War practically completed the destruction. Great efforts are now being made to train young people for the work of reconstruction. The greatest difficulty encountered in this task is the lack of books and text-books. The Association is particularly interested in books on medicine, and would be glad to receive such books, in English, German or French; volumes of the Lancet, Medical Officer, Nature, etc., would provide university libraries with material indispensable for the work both of students and staff. Correspondence should be sent to the president, Dr. Bæ̧Jedlewski, 43 Eaton Place, London, S.W.1. 